

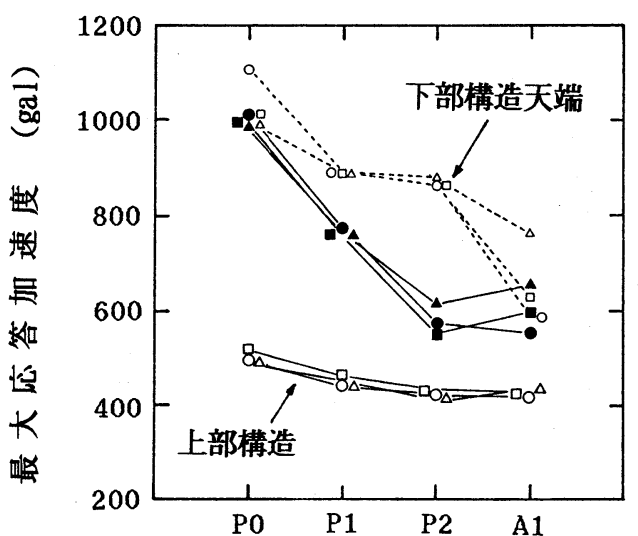

(a ) 上部構造・下部構造天端の最大応答加速度

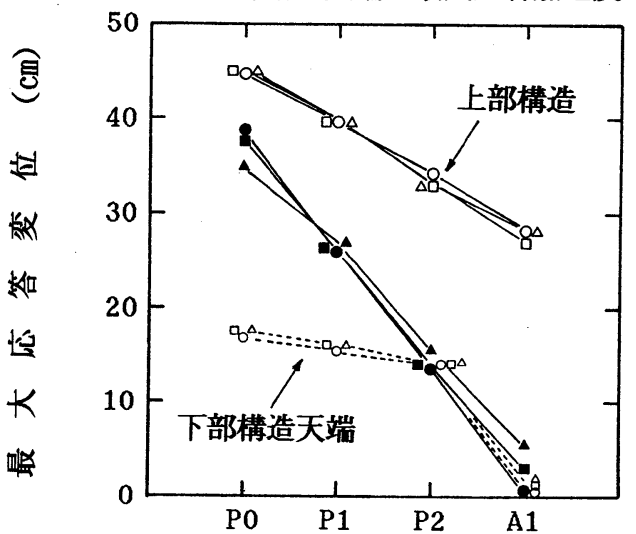

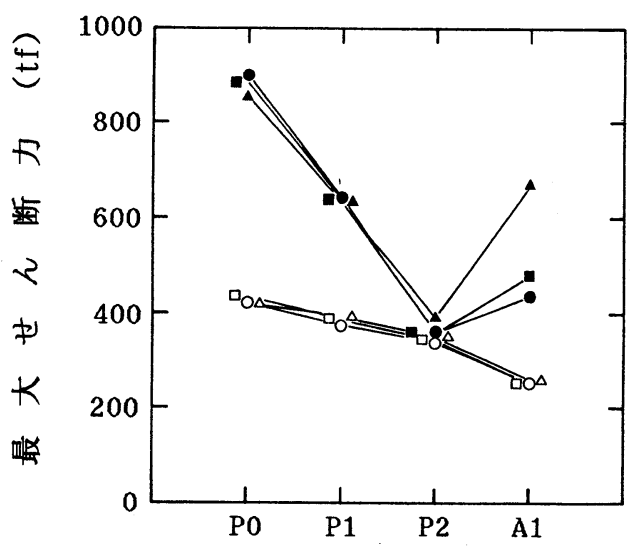

（c）下部構造基部の最大せん断力

\begin{tabular}{|c|c|c|}
\hline & 免 震橋 & 非免震橋 \\
\hline 直線橋 & $-0-$ & $-0-$ \\
\hline 曲線椅 $\quad R=105.0 \mathrm{~m}$ & 一ロ— & $-\square-$ \\
\hline 曲線橋 $\mathrm{R}=52.5 \mathrm{~m}$ & $-\Delta-$ & $-\Delta-$ \\
\hline
\end{tabular}

図-3 曲線半径之最大応答值分布の関係 （橋軸直角方向）

(b) 上部構造・下部構造天端の最大応答変位

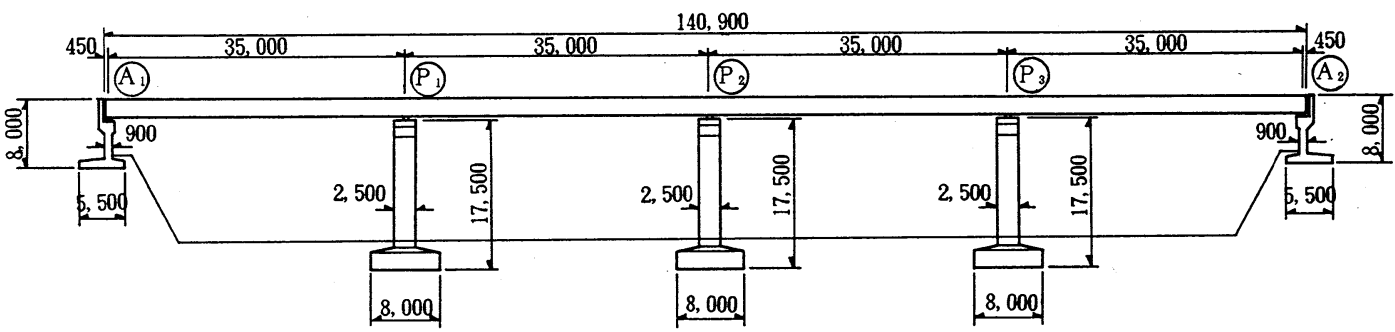

図-4 地震入力方向の影響の検討対象橋側面図

一方、全固定の非免震橋では、曲線 半径が小さくなるにつれてA1橋台部の 各応答值が大きくなつており、橋台の 応答の増大が上部構造慣性力の増大と して現れている。なお、図には示さな いが、橋脚およびA1橋台部の応答波形 はそれぞれ橋軸直角方向および橋軸方 向の基本モードが卓越している。

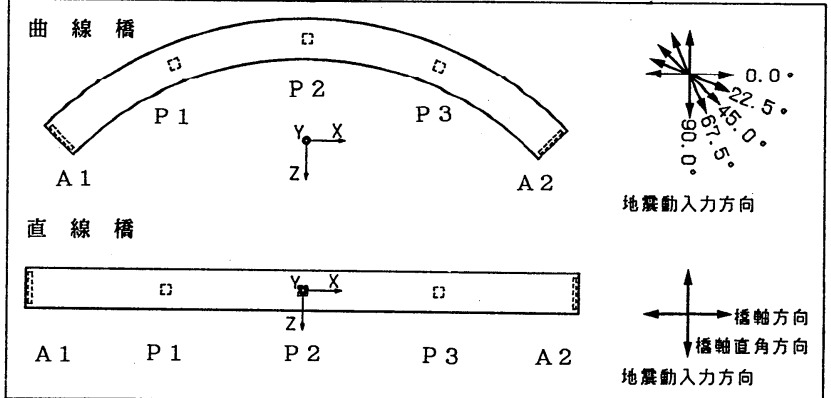

図－5 地震入力方向の影響の解析概念図 


\section{3. 地震入力方向の影響}

(1) 検討概要

曲線橋では、上部構造の軸が曲線に沿つて徐々に変化していくとともに、それを支持する橋脚や橋台が異 なった方向で配置される。上部構造は軸剛性が横剛性より大きく、下部構造も2 軸剛性に差がある場合があ るから、曲線橋では剛性の方向性が徐々に変化することになる。そこで、免震橋と全固定の非免震橋につい て地震入力方向をパラメータとした解析を行い、その地震応答の方向性を調べた。

検討対象橋は図 - 4 に示す 4 径間連続 P C 析橋である。図ー 5 に示すように、両析端のなす角が $90^{\circ}$ であ るような円弧状の平面線形をもつた曲線橋を考え、 $22.5^{\circ}$ つつ異なつた 5 方向からの地震入力を与えた時刻 歴応答解析を行つた。また、比較のために直線橋の橋軸方向および橋軸直角方向の解析も行つた。

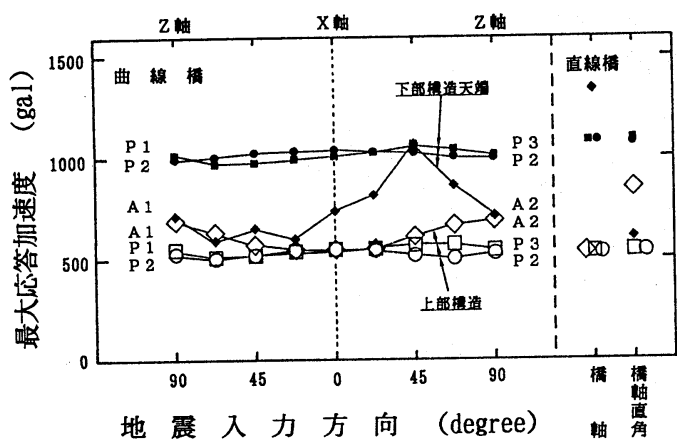

（a ）上部構造・下部構造天端の最大応答加速度

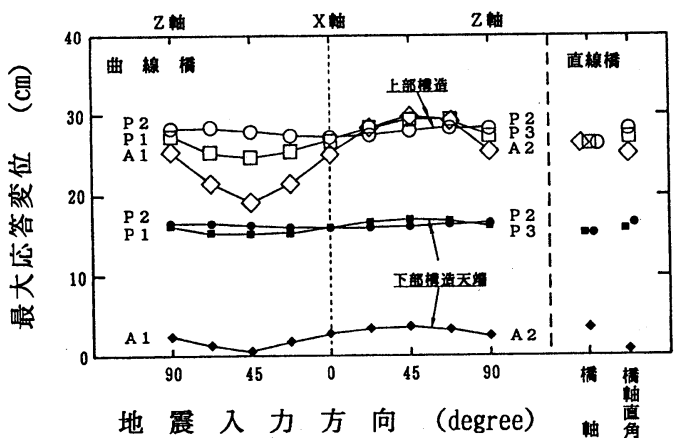

(b) 上部構造 -下部構造天端の最大応答変位

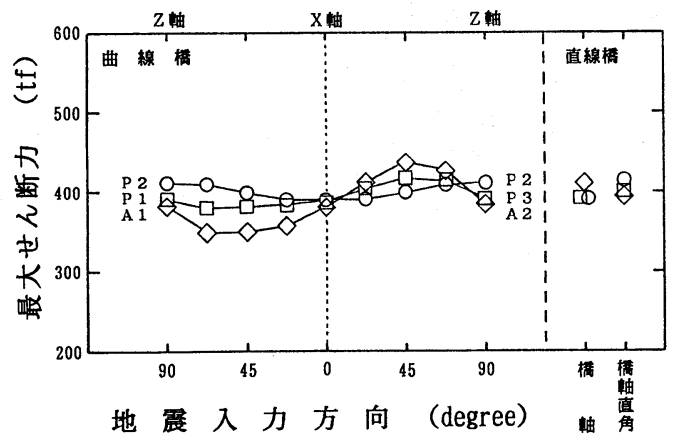

（c）下部構造基部の最大せん断力

図-6 地震入力方向と最大応答値の関係 （免震橋）

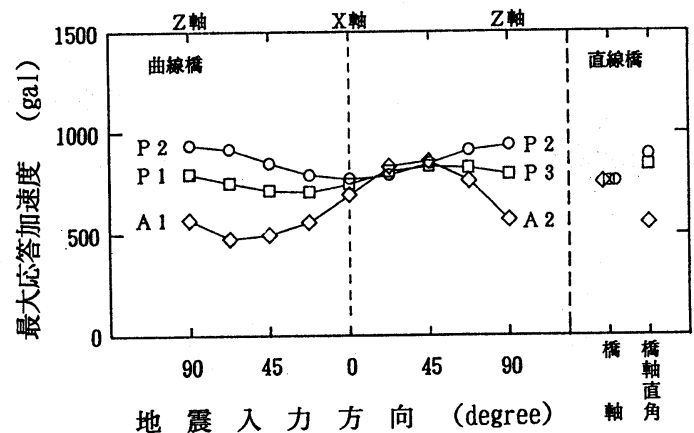

(a ）上部構造・下部構造天端の最大応答加速度

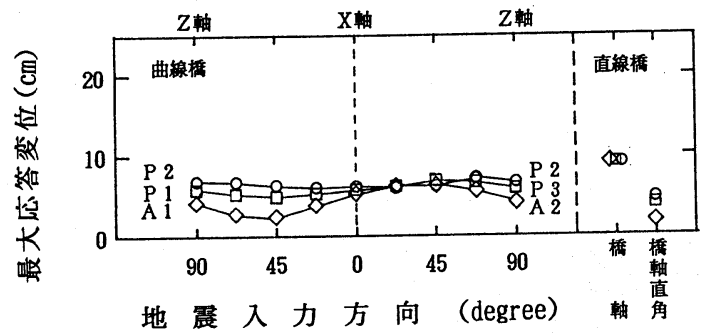

(b) 上部構造・下部構造天端の最大応答変位

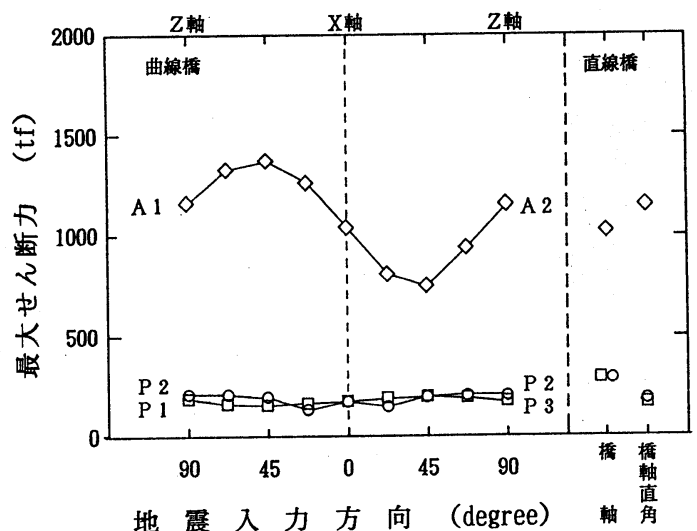

（c）下部構造基部の最大せん断力

図-7 地震入力方向と最大応答值の関係 （非免震橋） 
（2）解析方法（2．（2）と同じ）

(3) 検討結果

図ー6および図ー7は、それぞれ 免震橋および非免震橋について、地 震入力方向の変化に伴う最大応答値 の変化を示したものである。モデル の対称性を考慮して、A1とA2橋台、 P1とP3橋脚の値を左右対称にプロッ トし、同一線で結んでいる。これら の図から以下のことがわかる。

(1) 免震橋についてみると、曲線橋 の $0.0^{\circ}$ および $90.0^{\circ}$ 方向入力時に
表 -1 斜め $45^{\circ}$ 方向入力時の橋梁両端部の最大応答

\begin{tabular}{|c|c|c|c|c|}
\hline & & \multicolumn{2}{|c|}{ 曲線橋／直線橋 } & $\mathrm{A} 1$ 橋台 \\
\hline & & $A 1$ 橋台 ${ }^{11}$ & A2橋台 ${ }^{2)}$ & A2橋台 \\
\hline 上部構造の & 免 震 橋 & 0.670 & 1.137 & 0.937 \\
\hline 最大応答加速度 & 非免震橋 & 0.893 & 1.122 & 0.579 \\
\hline 支承の & 免 震 橋 & 0.762 & 1.138 & 0.692 \\
\hline 最大相対変位 & 非免震橋 & $=$ & $=$ & - \\
\hline 支承の & 免 震 橋 & 0.837 & 1.100 & 0.780 \\
\hline 最大せん断力 & 非免震橋 & 1.236 & 0.681 & 2.115 \\
\hline 下部構造基部の & 免 震 橋 & 0.888 & 1.063 & 0.800 \\
\hline 最大せん断力 & 非免震橋 & 1.192 & 0.726 & 1.835 \\
\hline
\end{tabular}

1) 直線橋の橋軸直角方向入力時の最大応答値との比

2）直線橋の橋軸方向入力時の最大応答値との比

おける上部構造、橋脚天端の応答加速度、変位 は、それぞれ直線橋の橋軸および橋軸直角方向 表 -2 免震装置 上部構造系の斜め $45^{\circ}$. 方向入力時 の桁両端部の最大応答値の比 の応答に対応し、曲線橋の斜め $45.0^{\circ}$ 方向入力 時のA1およびA2橋台天端の応答は、それぞれ直 線橋橋台の橋軸直角および橋軸方向の応答に対 応している。このことは、上下部構造が免震装 置でアイソレートされていて互いの拘束が小さ

\begin{tabular}{|l|c|}
\hline & $\mathrm{A} 1$ 橋台 $/ \mathrm{A} 2$ 橋台 \\
\hline 上部構造の最大応答加速度 & 0.958 \\
\hline 上部構造の最大応答変位 & 0.726 \\
\hline 免震装置の最大せん断力 & 0.868 \\
\hline
\end{tabular}
いために、各々の方向性を反映して自由に振動していることを示している。

(2) 非免震橋については、曲線橋上部構造の $0.0^{\circ}$ および $90.0^{\circ}$ 方向入力時における応答加速度、変位の分 布は、それぞれ直線橋の橋軸および橋軸直角方向の応答分布に対応している。曲線橋と直線橋とで橋梁全体 の剛性が異なるために、応答変位の絶対値は異なっている。

(3) 斜め $\left(22.5 \sim 67.5^{\circ}\right)$ 方向入力時の上部構造加速度（慣性力）は、免震橋ではモデル両側で違いが小さ く、 $0.0^{\circ}$ と $90.0^{\circ}$ 方向入力時の中間の值である。非免震橋ではA1、P1側で減少し、A2、P3側で増大する。

(4) 斜め方向入力時の上部構造変位は、免震橋、非免震橋ともに、A1、P1側で減少し、A2、P3側で増大する。

(5) 斜め方向入力時の下部構造基部の断面力は、免震橋ではA1、P1側で減少し、A2、P3側で増大する。非免 震橋では逆にA1、P1側で増大し、A2、P3側で減少する。

(6) (3)〜(5)に述べた応答值の増減は、橋梁の端部ほど強く、斜め $45.0^{\circ}$ 方向入力時に最も強く現れる。 表 -1 は、応答値の増減が最も強く現れる斜め $45.0^{\circ}$ 方向入力時の橋台部の最大応答値について、曲線橋 と直線橋の比および曲線橋両端の比として示したものであり、以下のことがいえる。

(7) 地震入力方向の変化に伴う応答值の増減は、免震橋では変位に、非免震橋では力に対して強く現れる。

（8) 地震入力方向の変化に伴う応答值の増減は、免震橋では非免震橋よりも小さい。

また、下部構造を取り除いた免震装置〜上部構造系のモデルに対して斜め $45.0^{\circ}$ 方向の地震入力による応 答を解析してみたところ表－2の結果を得た。表－1と良く対応していることから次のことが考えられる。

(9) 曲線免震橋では免震装置〜 上部構造系が慣性力分担に関して重要な役割をもち、全固定の曲線非免震橋 では下部構造の剛性比により分担率が決まる。

4. まとめ 免震曲線橋について曲線半径および地震入力方向に着目した解析を行い、以下の結論を得た。

(1) 免震曲線橋の上部構造慣性力は、曲線半径、地震入力方向にかかわらず、免震直線橋とほぼ等しい。

(2) 地震入力方向によっては慣性力分担率が変化するが、免震橋では力よりも変位に対して大きく現れる。

5. おわりに 本報告は建設省土木研究所と民間 28 社との官民連帯共同研究「道路橋の免震構造システ ムの開発」の一環として行われたものである。 